\title{
Research Communication NKT Cells in the Induced Sputum of Severe Asthmatics
}

\author{
Agnes Hamzaoui,, ${ }^{1,2}$ Sana Cheik Rouhou, ${ }^{1,2}$ Hedia Graïri, ${ }^{1,2}$ Hanadi Abid, 1,2 \\ Jamel Ammar, ${ }^{1,2}$ Hanene Chelbi, $^{2}$ and Kamel Hamzaoui ${ }^{2}$ \\ ${ }^{1}$ Department of Pediatric and Respiratory Diseases, Abderrahmane Mami Hospital, Pavillon B, Ariana 2080, Tunisia \\ ${ }^{2}$ Homeostasis and Cell Dysfunction Unit Research 99/UR/08-40, Medicine University of Tunis, 1007 Tunis, Tunisia
}

Received 24 October 2005; Accepted 9 December 2005

\begin{abstract}
To determine whether there was a specific inflammatory process in severe asthmatics, the phenotypic characteristics of induced sputum immune cells were analysed among patients with severe asthma. Twenty-two induced sputa (10 severe asthmatics) were studied. Flow cytometric analysis was performed using immune cells of the sputum and monoclonal antibodies to CD3, CD4, $\mathrm{CD} 8, \mathrm{CD} 56, \mathrm{CD} 25$, and TCR $\gamma \delta$. The number of NKT $\left(\mathrm{CD}^{+} \mathrm{CD}^{+} 6^{+}\right)$cells was significantly higher in the sputum of severe asthmatics compared with mild asthmatic and healthy control groups $(P<.05)$. CD $8^{+} \mathrm{CD} 56^{+}$cells were the predominant subtype of the increased NKT cells in severe asthmatics. $\mathrm{CD} 3^{+} \mathrm{CD} 56^{+} \mathrm{V} \alpha 24^{+}, \mathrm{TCR} \gamma \delta^{+} \mathrm{CD} 56^{+}$, and $\mathrm{CD} 4{ }^{+} \mathrm{CD} 25^{+} \mathrm{T}$ cells were significantly increased in severe asthmatic patients. These results suggest that the immunopathogenesis of severe asthmatics vary between severe and mild asthmatics, and that $\mathrm{CD} 8^{+} \mathrm{CD} 56^{+}$NKT cells may play an important role in the immunopathogenesis of severe asthma.
\end{abstract}

Copyright (C) 2006 Agnes Hamzaoui et al. This is an open access article distributed under the Creative Commons Attribution License, which permits unrestricted use, distribution, and reproduction in any medium, provided the original work is properly cited.

\section{INTRODUCTION}

Asthma is recognized by the presence of reversible bronchoconstriction, airway hyperresponsiveness, and airway inflammation [1]. These clinical features result from a chronic inflammation of the airways, caused by a migration of leucocytes and an increase of inflammatory mediators in the bronchial wall [2]. This pathological reaction in asthma is thought to arise from a complex interaction between genes and the environment. Different immunopathogenic mechanisms and immune cells may be involved in the development of asthma [3], natural killer T (NKT) cells constitute one of the regulatory cells not well defined in asthma.

Natural killer T (NKT) cells are heterogeneous T-cell populations that are characterised by the coexpression of TCRs and various NK receptors, including CD16, CD56, CD161, CD94, CD158a, and CD158b [4]. NKT cells have been considered to regulate autoimmunity and adaptive immune responses [4-6], even though the pleiotropic nature of NKT cells creates some controversy regarding their functional role at different inflammatory sites [7-10]. Disturbances in the numbers and functions of the NKT cells have been implicated in several organ-specific animal models of autoimmunity as well as in humans [11,12]. The proportion of NKT cells among the induced sputum cells in the severe asthmatic patients has not yet been studied.
Therefore, in this study we asked whether there are phenotypic differences in the sputum immune cell types, including the NKT cells, in patients with severe asthma and in patients with mild asthma. The subtypes of $\mathrm{CD}^{+} 6^{+} \mathrm{T}$ cells, including $\gamma \delta \mathrm{T}$ cells, $\mathrm{V} \alpha 24^{+} \mathrm{T}$ cells, and $\mathrm{CD} 8^{+} \mathrm{CD} 56^{+} \mathrm{T}$ cells, were analysed.

\section{PATIENTS AND METHODS}

\section{Patients}

Induced sputum samples were collected from 22 successive patients with asthma (10 patients in severe asthma) (Table 1). All were outpatients in steady state, regulatory followed by an asthma specialist. The severity of the disease was classified according to GINA recommendations [13]. The samples were obtained on the day of the fixed visit. A precise history of the patient was previously obtained with functional respiratory tests. The following patients were excluded: acute exacerbation of asthma, concomitant respiratory infection, other pulmonary diseases, and smokers.

Ten induced sputum from healthy subjects-females with a mean age of 28.7 years (range 18-39 years), who had normal pulmonary radiographs and showed no clinical signs of respiratory diseases-acted as controls. Informed consent was obtained from all the patients. The study was approved by our Ethics Committee. 
TABLE 1: Cellular characteristics of induced sputum. Differential sputum cell counts are expressed as percentage of nonsquamous cells.

\begin{tabular}{lccc}
\hline & Healthy controls & Severe asthmatics & Mild asthmatics \\
\hline Number/Sex (F) & $10(\mathrm{~F})$ & $10(\mathrm{~F})$ & $12(\mathrm{~F})$ \\
Age & $28.7 \pm 6.2$ & $48.6 \pm 3.5$ & $55.2 \pm 3.2$ \\
FEV $_{1}$ (\% predicted) & $93.2 \pm 4.8$ & $58.7 \pm 6.2^{\dagger}$ & $87.3 \pm 2.5$ \\
Total cell count (10 $/ \mathrm{ml})$ & $1.65 \pm 0.7$ & $3.1 \pm 0.5^{\dagger}$ & $1.9 \pm 0.32$ \\
Macrophages (\%) & $47.6 \pm 5.2$ & $33.6 \pm 8$ & $48.9 \pm 4.5$ \\
Neutrophils (\%) & $30 \pm 4.5$ & $29.2 \pm 4.9$ & $25.7 \pm 6.1$ \\
Eosinophils (\%) & $0.7 \pm 0.2$ & $5.7 \pm 3.6^{\dagger}$ & $1.2 \pm 0.7$ \\
Lymphocytes (\%) & $1.7 \pm 1.2$ & $6.5 \pm 2^{\dagger}$ & $2.7 \pm 1.8$ \\
Squamous cells (\%) & $4.5 \pm 2$ & $4.8 \pm 1.9$ & 8.9 \\
Viability (\%) & $84 \pm 4$ & $82 \pm 6$ & $87 \pm 5$ \\
\hline
\end{tabular}

† significant differences $(p<.05)$ compared to mild asthmatic patients and healthy controls. Successful sputum induction was achieved in $9 / 10$ severe asthmatics and $8 / 12$ mild asthmatics.

\section{Sputum induction and processing}

Before sputum induction all patients inhaled salbutamol $(200 \mu \mathrm{g})$ via a metered dose inhaler. Baseline $\mathrm{FEV}_{1}$ was measured and this was repeated following salbutamol and after each 5-minute inhalation of nebulised hypertonic saline $(3.5 \%)$. The procedure was stopped if the $\mathrm{FEV}_{1}$ fell by $>10 \%$ following saline or by $>20 \%$ at any time during the induction procedure. Solid sputum material was separated from saliva before processing as we have recently reported [14]. Briefly, selected sputum was weighed and 0.1\% DTT (SigmaAldrich, Poole, UK) in phosphate-buffered saline (PBS) was added at a ratio of $4 \mathrm{ml}$ to $1 \mathrm{~g}$ sputum. The sputum was incubated with DTT at room temperature for 15 minutes on a rolling mixer. The same volume ( $4 \mathrm{ml}$ to $1 \mathrm{~g}$ sputum) of PBS was added to the sputum and then filtered through $48 \mu \mathrm{m}$ nylon gauze. The filtrate was centrifuged at $400 \mathrm{~g}$ (Sorvall RT6000D, Kendro, Bishop's Stortford, UK) for $10 \mathrm{~min}$ utes at $4^{\circ} \mathrm{C}$ to pellet cells. The cells were resuspended in PBS containing $0.1 \%$ bovine serum albumin (BSA). The viability of the sample was determined by trypan blue exclusion staining (Sigma-Aldrich) in a Neubauer hemocytometer (Merck Eurolabs, Lutterworth, UK). Cytospins (Shandon Scientific, Sewickley, Pa, USA) of sputum cells that were used for determination of differential cell counts were fixed with methanol and stained with May-Grunwald-Giemsa stain (Merck-Eurolabs).

\section{Flow cytometric analysis}

Two-colour staining of the sputum cells was performed using monoclonal antibodies (mAbs) in two combinations: tube A contained mAbs to CD4 (helper T cell)/CD8 (cytotoxic $\mathrm{T}$ cell), and tube $\mathrm{B}$ contained mAbs to CD3 (pan $\mathrm{T}$ cell)/CD56 (natural killer cell) (all were products of BD Biosciences). The isotype-matched control mAbs were used. $50 \mu \mathrm{l}$ aliquots of the mononuclear cells from the sputum cells were added to the polypropylene round-bottom test tube, and the directly conjugated mAbs (conjugated fluorescein isothiocyanate (FITC), phycoerythrin (PE), CyChrome (Cy), or peridinin chlorophyll-a protein (PerCP)) were added at predetermined optimal dilution. After a 30minute incubation, aliquots were washed twice in FACS buffer (phosphate-buffered saline/0.2\% bovine serum albumin). The acquisition was performed using a FACSCalibur flow cytometer (Becton Dickinson), and analysed using the CellQuest software program (BD Biosciences). A gate for the live lymphocyte population was defined by the forward and side scatter characteristics, and the data was displayed on a log scale of increasing fluorescence intensity. In addition, the subtype analysis of $\mathrm{CD} 3^{+} \mathrm{CD} 56^{+}$cells was done in the sputum of patients with severe asthma and mild asthma. The subtype analysis was also done to 10 healthy controls for the comparison. $\mathrm{CD}^{+} \mathrm{CD}^{+} 6^{+} \mathrm{T}$ cells belong to a highly heterogeneous subset that includes chronically stimulated conventional $\mathrm{CD}^{+} \mathrm{T}$ cells, $\mathrm{T}$ cells, and so called CD1d-restricted NKT cells, the hallmark of which is the recurrent expression of $\mathrm{V} \alpha 24 \mathrm{~V} \beta 11 \mathrm{~T}$-cell receptors [15]. For the further detailed phenotypic analysis of $\mathrm{CD}^{+} \mathrm{CD}^{+} 6^{+} \mathrm{T}$ cells, three- or fourcolour staining, using CD3, CD56, CD25, and additional markers such as pan TCR $\gamma \delta \mathrm{mAb}$, pan TCR $\beta \mathrm{mAb}, \mathrm{CD} 4$, and CD8 coreceptors and $\mathrm{V} \alpha 24 \mathrm{~V} \beta 11$ (all were products of BD Biosciences) was done.

\section{Statistics}

The differences in the phenotypic characteristics of the mononuclear cell populations among the patients with severe asthma, mild asthma, and healthy controls were statistically compared using Anova test. For significant Anova values, the groups were compared by a Tukey's post hoc test for the multiple comparisons with an unequal cell size. A $P$ value $<.05$ was considered significant. In addition, the Wilcoxon matched-pair signed-rank test was used to demonstrate the differences between the values obtained from the sputum cells of severe and mild asthmatics. 
TABLe 2: Percentages of lymphocyte subsets and CD4/CD8 ratio in the induced sputum of healthy control, mild asthmatic, and severe asthmatic patients.

\begin{tabular}{lccc}
\hline & Healthy controls & Severe asthmatics & Mild asthmatics \\
\hline $\mathrm{CD}^{+}$ & $91.42 \pm 8.35$ & $93.12 \pm 6.11$ & $94.21 \pm 7.12$ \\
$\mathrm{CD} 4^{+}$ & $65.5 \pm 18.66$ & $72.65 \pm 10.22^{\dagger}$ & $68.6 \pm 9.33$ \\
$\mathrm{CD}^{+}$ & $25.6 \pm 17.2$ & $18.6 \pm 9.8^{\dagger}$ & $23.6 \pm 8.7$ \\
$\mathrm{CD} 4^{+} / \mathrm{CD}^{+}$ & $1.97 \pm 0.7$ & $3.58 \pm 0.37^{\dagger \dagger}$ & $2.57 \pm 0.29^{\dagger}$ \\
$\mathrm{CD} 19^{+}$ & $6.33 \pm 1.82$ & $5.32 \pm 1.07$ & $4.30 \pm 0.98$ \\
$\mathrm{TCR} \gamma \delta^{+}$ & $2.63 \pm 1.72$ & $9.63 \pm 0.28^{\dagger \dagger}$ & $1.97 \pm 0.63$ \\
$\mathrm{CD} 4^{+} \mathrm{CD} 25^{+}$ & $5.25 \pm 1.45$ & $9.44 \pm 0.63^{\dagger \dagger}$ & $3.23 \pm 0.30$ \\
\hline
\end{tabular}

${ }^{\dagger}$ significantly different from healthy controls. ${ }^{\dagger \dagger}$ significantly different from healthy controls and mild asthmatic patients.

TABLe 3: Percentages of subpopulations of NKT $\left(\mathrm{CD}^{+} \mathrm{CD}^{+} 6^{+}\right)$cells and NK $\left(\mathrm{CD} 3^{-} \mathrm{CD} 56^{+}\right)$cells in the induced sputum of patients with severe asthma, mild asthma, and healthy controls.

\begin{tabular}{lccr}
\hline & Healthy controls & Severe asthma & Mild asthma \\
\hline $\mathrm{CD}^{+} \mathrm{CD} 56^{+}$ & $2.14 \pm 1.72$ & $13.52 \pm 4.13^{\dagger \dagger}$ & $2.86 \pm 1.39$ \\
$\mathrm{CD} 4^{+} \mathrm{CD} 56^{+}$ & $0.30 \pm 0.20$ & $0.58 \pm 0.32$ & $0.29 \pm 0.07$ \\
$\mathrm{CD}^{+} \mathrm{CD} 56^{+}$ & $2.05 \pm 0.29$ & $7.43 \pm 1.05^{\dagger}$ & $2.83 \pm 1.45$ \\
$\mathrm{CD}{ }^{-} \mathrm{CD} 56^{+}$(NK cells) & $3.25 \pm 0.29$ & $5.58 \pm 4.72$ & $3.83 \pm 1.45$ \\
$\mathrm{CD} 56^{+} \alpha \beta$ TCR & $0.93 \pm 0.18$ & $6.12 \pm 1.29^{\dagger}$ & $0.92 \pm 0.87$ \\
$\mathrm{CD} 56^{+} \gamma \delta$ TCR & $0.97 \pm 0.25$ & $6.50 \pm 3.74^{\dagger}$ & $0.89 \pm 0.45$ \\
$\mathrm{CD} 56^{+} \mathrm{V} \alpha 24^{+}$T cells & $0.09 \pm 0.02$ & $0.82 \pm 0.07^{\dagger \dagger}$ & $0.07 \pm 0.05$ \\
\hline
\end{tabular}

t† denotes statistically significant differences of the value when compared with that of patients with mild asthma and healthy controls $(P<.05)$.

\section{RESULTS}

\section{Cell types in induced sputum of severe and mild asthmatics}

Subject sputum cell counts characteristics were as summarised in Table 1. Baseline $\mathrm{FEV}_{1}$ expressed as percentage predicted differed significantly between severe asthmatics and mild asthmatics $(P<.01)$. There were significant differences in the total cell count of the sputum cells between patients with severe asthma compared to patients with mild asthma and healthy controls $(P<.05)$. Significant differences were observed in the percentages of eosinophils and lymphocytes between severe asthmatics and mild asthmatics $(P<.01)$.

The sputum from the asthmatic patients was analysed for the percentages of B cells (CD19), $\mathrm{CD}_{4}^{+}$, and $\mathrm{CD}^{+} \mathrm{T}$-cell subsets among the lymphocytes. The phenotypes of the immune cells showed significant differences between the sputum of severe and mild asthmatic patients (Table 2). A slight but not significant reduction of $\mathrm{CD} 19^{+}$cells was observed in severe and mild asthmatics comparatively to healthy controls. Decreased percentages of $\mathrm{CD} 8^{+} \mathrm{T}$-cells were observed in severe asthmatic. The percentage of $\mathrm{CD} 4^{+}$cells in the sputum of severe asthmatic patients was elevated resulting in a higher $\mathrm{CD}^{+} / \mathrm{CD}^{+} \mathrm{T}$-cell ratio compared to the sputum of mild asthmatics and healthy controls. There was a positive correlation between sputum CD4/CD8 ratio and the sputum percentage of eosinophils in severe asthmatic patients $(r=0.536, P<.05)$. Patients with severe asthma showed a higher TCR $\gamma \delta^{+}$cell percentage than mild asthmatics and healthy controls. Severe asthmatic patients expressed high level of $\mathrm{CD} 4{ }^{+} \mathrm{CD} 25^{+}$cells, when compared to mild asthmatics.

\section{Prevalence of $\mathrm{CD}^{+} \mathrm{CD}^{+} 6^{+} \mathrm{T}$ cells in severe asthmatic patients}

The proportions of $\mathrm{CD}^{+} \mathrm{CD}^{2} 6^{+}$cells in the sputum of patients with severe asthma were highly expressed when compared to patients with mild asthma and healthy controls (Table 3). No significant differences were observed in the $\mathrm{CD}^{-}{ }^{-} \mathrm{CD} 56^{+}$cells between mild and severe asthmatics.

The $\mathrm{CD}^{+}{ }^{+} \mathrm{CD} 6^{+} / \mathrm{CD}^{-}{ }^{-} \mathrm{CD} 56^{+}$cellular ratio was significantly increased in severe asthmatics compared to patients with mild asthma and healthy controls, because of the more dominance of the NKT cells $(P<.05)$, (Figure 1$)$.

\section{Phenotypic analysis of $C D 3^{+} C D 56^{+} T$ cells in patients with severe asthmatic}

The subsets of $\mathrm{CD}^{+} \mathrm{CD} 56^{+}$cells in patients with severe asthma and mild asthma were analysed in the sputum; we also analysed these cells in healthy controls (Table 3 ). The subsets of $\mathrm{CD}^{+} \mathrm{CD} 56^{+}$cells, especially $\mathrm{CD} 8^{+} \mathrm{CD} 56^{+}$ cells and $\mathrm{CD}^{2} 6^{+} \gamma \delta \mathrm{T}$ cells, were significantly increased in 


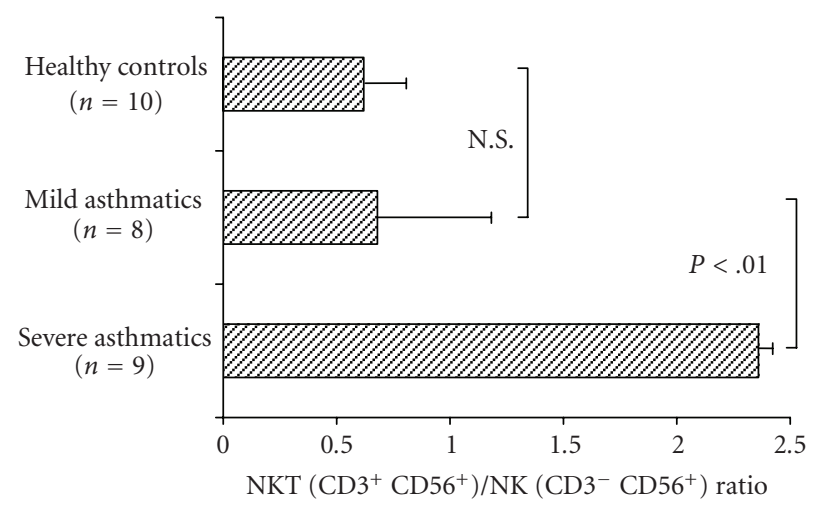

FIGURE 1: Ratio of NKT $\left(\mathrm{CD}^{+} \mathrm{CD}^{+} 6^{+}\right)$cells and NK $\left(\mathrm{CD} 3^{-} \mathrm{CD} 56^{+}\right)$cells in the induced sputum of patients with severe asthma, mild asthma, and healthy controls.

patients with severe asthmatics compared to healthy controls and mild asthmatics. $\mathrm{V} \alpha 24^{+} \mathrm{T}$ cells among $\mathrm{CD} 3^{+} \mathrm{CD} 56^{+}$ cells were significantly increased in severe asthmatics. $\mathrm{V} \alpha 24^{+}$ $\mathrm{T}$ cells did not show any statistically significant difference among the mild asthmatic group and healthy controls.

\section{DISCUSSION}

This study shows that sputum immune cells in severe asthmatic patients expressed different $\mathrm{CD} 3^{+} \mathrm{CD} 56^{+}$, $\mathrm{CD} 8^{+} \mathrm{CD} 56^{+}, \mathrm{CD}^{2} 6^{+} \gamma \delta \mathrm{CD}^{2} 6^{+} \mathrm{V} \alpha 24^{+} \mathrm{T}$ subpopulations, and NKT/NK cell ratio than patients with mild asthma. The values of $\mathrm{CD} 8{ }^{+} \mathrm{CD} 56^{+}$were similar as we have recently reported [14]. No differences were observed between healthy controls and mild asthmatics. These findings may be attributed to the fact that the aetiologies of the severe and mild asthma were different. $\mathrm{CD} 4^{+} \mathrm{T}$ cells were more predominant than $\mathrm{CD}^{+} \mathrm{T}$ cells in the sputum of mild and severe asthmatics. The $\mathrm{CD} 4^{+} \mathrm{T}$ cells in the sputum of severe asthmatic patients show increased CD25 expression, comparatively to mild asthmatics. CD25 characterise both activated cells and regulatory $\mathrm{T}$ cells (Treg), the most specific marker for Treg cells is Foxp3, a recently identified transcription factor gene that is specifically expressed in $\mathrm{CD} 4{ }^{+} \mathrm{CD} 25^{+}$Treg cells. The sputum eosinophils count was higher in severe asthmatics compared to mild asthmatics. Our study also confirms that inducted sputum is a safe method to investigate airway inflammation in asthma, as it has been reported by Jatakanon A et al [16].

Severe asthmatics exhibited an increase in CD4/CD8 cell ratio in comparison with mild asthmatic patients. The significantly higher $\mathrm{CD} 4 / \mathrm{CD} 8$ ratio confirms the enhancement of $\mathrm{CD}^{+}{ }^{+}$cells response in severe asthma. Increased CD4/CD8 ratios have been already suggested from severe asthmatics peripheral blood, bronchoalveolar lavage lymphocytes (BAL), and lung biopsy studies $[17,18]$. In the same line of our report, the recent study of Fabbri et al [19], severe asthmatics expressed a higher CD4/CD8 T-cell ratio, infiltrating the airway mucosa. On the contrary, Leckie et al [20] failed to find any difference in the number of sputum $\mathrm{CD} 4^{+}$and $\mathrm{CD}^{+}$cell populations of patients with asthma or healthy subjects. $\mathrm{CD} 4^{+}$cells of type 2 have also been found increased in blood, biopsies, and BAL of asthmatic patients $[17,21] . \mathrm{CD}^{+}$cells expressed regulatory cytokines, like IL5 that promotes eosinophil differentiation and activation, as well as IL-4 and IL-13, which induce IgE production and eosinophil recruitment via vascular cell adhesion molecule1 expression on the vascular endothelium [22]. Increased eosinophil cells were observed in our severe asthmatic patients. Eosinophils play a major role in the onset and maintenance of bronchial inflammation and tissue injury in asthma $[23,24]$. The sputum CD4/CD8 ratio in our severe asthmatic group correlate to the number of eosinophils, but did not correlate to IgE levels. Possibly, the higher CD4 cell numbers observed in our study among severe asthmatics also reflect a persisting release of Th2 cytokines from the above cells, which both support higher eosinophil levels, despite steroid treatment. In asthma, Th2 cytokines (IL-13) is elevated in BAL, bronchial biopsies, and sputum [25], and several cell types have been described as important sources of IL-13, including T-lymphocytes [26, 27]. The role of eosinophils in severe asthmatics is not clear. Wenzel et al [28] have demonstrated that there are two subtypes of severe asthma, depending on the absence or presence of eosinophils in endobronchial biopsies. Sputum analysis of severe asthmatics has provided evidence for persistent eosinophilic inflammation $[17,19]$. Similarly, our asthmatic group had significantly higher eosinophil percentages. Gibson et al [29] have already reported heterogeneity regarding sputum eosinophil numbers in severe asthmatics.

In this study, $\mathrm{CD}^{+}{ }^{+} \mathrm{CD} 56^{+}$cell population was much higher in the sputum of severe asthmatic patients than patients with mild asthma and healthy controls. These results indicate that $\mathrm{CD}^{+}{ }^{+} \mathrm{CD} 56^{+}$cells may play a key role only in the pathogenesis severe asthma. Ohkawa et al [30] suggested that human $\mathrm{CD}^{+} 6^{+} \mathrm{T}$ cells play an important role in the Th1 responses. In severe asthmatics, $\mathrm{CD} 3^{+} \mathrm{CD} 56^{+}$-cytokines production is under studies. Activated $\mathrm{T}$ cells with NK cell 
markers (NKT cells) in our severe asthmatics may be harmful to the lung. TCR $\gamma \delta$ T cells with or without CD56 were increased in sputum of severe asthmatic patients compared to mild asthma. TCR $\gamma \delta$ cells are predominantly $\mathrm{CD} 4^{-} \mathrm{CD} 8^{-}$ T lymphocytes, appear early in thymic ontogeny, consist $1 \%$ to $10 \%$ of the peripheral blood $\mathrm{T}$ cells, and are dispersed in lymphatic and extralymphatic tissues. TCR $\gamma \delta$ cells work as first-line defending cells of the innate immune response and are thought to influence the nature of the adaptive immune response [31]. T cells expressing NK receptors are believed to play key roles in patrolling, surveying, and destroying cells with an abnormal phenotype [32]. T cells expressing the $\gamma \delta$-receptor have been reported to be essential for Th2mediated inflammation in patients with acute exacerbation of asthma [33]. In IL-12 rich microenvironments, CD56 expression was induced from $\mathrm{T}$ cells, which exerted potent cytotoxicity [34].

The predominance of $\mathrm{CD}^{+} \mathrm{CD}^{2} 6^{+}$cells might be related to the chronic and massive tissue inflammation observed in severe asthmatics. In certain autoimmune disease, tissue destruction is dominated by $\mathrm{CD}^{+} \mathrm{T}$ cells in the chronic stage [35]. The importance of these cells in the development of branchial inflammation in severe asthma is further supported by the fact that $\mathrm{CD} 8^{+} \mathrm{CD} 56^{+}$cells is more prominent in the sputum of severe asthmatics rather than in the sputum of mild asthmatics. Pittet et al [36] suggested that the CD8 ${ }^{+}$ cytotoxic T lymphocyte (CTL) effector function correlates better with CD56 surface expression. Based on the tight association between cytolytic effector function and CD56 expression, they proposed that CD56 represents a useful marker to identify and monitor effector $\mathrm{CD}^{+} \mathrm{T}$ cells in different clinical situations. These immune cells with cytolytic effector potential may contribute to the more chronic and destructive nature that is mediated by $\mathrm{CD}^{+} \mathrm{T}$ cells. Functional study such as cytotoxic functional assay will be necessary in order to determine the exact pathogenic role of $\mathrm{CD} 8^{+} \mathrm{CD} 56^{+}$cells in severe asthmatics.

In summary, the $\mathrm{CD} 4^{+} \mathrm{T}$ cells were prominent in the sputum of the patients with severe asthma. Despite decreased $\mathrm{CD}^{+} \mathrm{T}$ cells observed in severe asthmatics, the number of $\mathrm{CD} 8{ }^{+} \mathrm{CD} 6^{+}$cells was the predominant subtype, subscribing an increase of NKT cells in severe asthmatics than the other groups. These results suggest that the immunopathogenesis of severe asthma is different than mild asthma, and that $\mathrm{CD}^{+} \mathrm{CD} 56^{+} \mathrm{NKT}$ cells may play an important role in the immunopathogenesis of severe asthma. The identification and analysis of the T lymphocytes from the sputum can assist in understanding the role of T cells in the pathogenesis of the different groups of asthma. The increased infiltration of the sputum by NK/NKT cells favors recovery? This information may help to characterise the pathogenesis of severe asthma.

\section{ACKNOWLEDGMENT}

This study was supported by the grant from "Secrétariat d'Etat à la Recherche Scientifique of Tunisia."

\section{REFERENCES}

[1] Sheffer AL. Guidelines for the diagnosis and management of asthma. National Heart, Lung and Blood Institute. National Asthma Education Program. Expert Panel Report. Journal of Allergy and Clinical Immunology. 1991;88(3 pt 2):425-534.

[2] Bittleman DB, Casale TB. Allergic models and cytokines. American Journal of Respiratory and Critical Care Medicine. 1994;150(5 pt 2):S72-S76.

[3] Wills-Karp M, Karp CL. Chitin checking-novel insights into asthma. The New England Journal of Medicine. 2004;351(14): 1455-1457.

[4] Godfrey DI, Hammond KJ, Poulton LD, Smyth MJ, Baxter AG. NKT cells: facts, functions and fallacies. Immunology Today. 2000;21(11):573-583.

[5] van der Vliet HJ, von Blomberg BM, Nishi N, et al. Circulating $\mathrm{V} \alpha 24^{+} \mathrm{V} \beta 11^{+} \mathrm{NKT}$ cell numbers are decreased in a wide variety of diseases that are characterized by autoreactive tissue damage. Clinical Immunology. 2001;100(2):144-148.

[6] Wilson SB, Kent SC, Patton KT, et al. Extreme Th1 bias of invariant $\mathrm{V} \alpha 24 \mathrm{~J} \alpha \mathrm{Q}$ T cells in type 1 diabetes. Nature. 1998; 391(6663):177-181.

[7] Shi F-D, Ljunggren HG, Sarvetnick N. Innate immunity and autoimmunity: from self-protection to self-destruction. Trends in Immunology. 2001;22(2):97-101.

[8] Mempel M, Ronet C, Suarez F, et al. Natural killer T cells restricted by the monomorphic MHC class $1 \mathrm{~b}$ CD1d 1 molecules behave like inflammatory cells. The Journal of Immunology. 2002;168(1):365-371.

[9] Smyth MJ, Godfrey DI. NKT cells and tumor immunity-a double-edged sword. Nature Immunology. 2000;1(6):459-460.

[10] Cui J, Watanabe N, Kawano T, et al. Inhibition of $\mathrm{T}$ helper cell type 2 cell differentiation and immunoglobulin E response by ligand-activated V $\alpha 14$ natural killer T cells. The Journal of Experimental Medicine. 1999;190(6):783-792.

[11] Mieza MA, Itoh T, Cui JQ, et al. Selective reduction of $\mathrm{V} \alpha 14^{+} \mathrm{NK} \mathrm{T}$ cells associated with disease development in autoimmune-prone mice. The Journal of Immunology. 1996; 156(10):4035-4040.

[12] Kukreja A, Costi G, Marker J, et al. NKT cell defects in NOD mice suggest therapeutic opportunities. Journal of Autoimmunity. 2002;19(3):117-128.

[13] NHBLI/WHO. Global initiative for asthma. Global strategy for asthma management and prevention. Bethesda, Md: National Institutes of Health; 1995. NHBLI/WHO Workshop Report 95-3659.

[14] Hamzaoui A, Chaouch N, Graïri H, Ammar J, Hamzaoui K. Inflammatory process of $\mathrm{CD}^{+} \mathrm{CD} 28^{-} \mathrm{T}$ cells in induced sputum from asthmatic patients. Mediators of Inflammation. 2005; (3):160-166.

[15] Musha N, Yoshida Y, Sugahara S, et al. Expansion of CD56 ${ }^{+}$ NK T and $\gamma \delta$ T cells from cord blood of human neonates. Clinical and Experimental Immunology. 1998;113(2):220-228.

[16] Jatakanon A, Uasuf C, Maziak W, Lim S, Chung KF, Barnes PJ. Neutrophilic inflammation in severe persistent asthma. American Journal of Respiratory and Critical Care Medicine. 1999;160(5 pt 1):1532-1539.

[17] Colavita AM, Reinach AJ, Peters SP. Contributing factors to the pathobiology of asthma. The Th1/Th2 paradigm. Clinics in Chest Medicine. 2000;21(2):263-277, viii.

[18] Tsoumakidou M, Tzanakis N, Kyriakou D, Chrysofakis G, Siafakas NM. Inflammatory cell profiles and T-lymphocyte 
subsets in chronic obstructive pulmonary disease and severe persistent asthma. Clinical \& Experimental Allergy. 2004;34(2):234-240.

[19] Fabbri LM, Romagnoli M, Corbetta L, et al. Differences in airway inflammation in patients with fixed airflow obstruction due to asthma or chronic obstructive pulmonary disease. American Journal of Respiratory and Critical Care Medicine. 2003;167(3):418-424.

[20] Leckie MJ, Jenkins GR, Khan J, et al. Sputum T lymphocytes in asthma, COPD and healthy subjects have the phenotype of activated intraepithelial T cells $\left(\mathrm{CD} 69^{+} \mathrm{CD} 103^{+}\right)$. Thorax. 2003;58(1):23-29.

[21] Brightling CE, Symon FA, Birring SS, Bradding P, Pavord ID, Wardlaw AJ. TH2 cytokine expression in bronchoalveolar lavage fluid $\mathrm{T}$ lymphocytes and bronchial submucosa is a feature of asthma and eosinophilic bronchitis. Journal of Allergy and Clinical Immunology. 2002;110(6):899-905.

[22] Muro S, Minshall EM, Hamid QA. The pathology of chronic asthma. Clinics in Chest Medicine. 2000;21(2):225-244.

[23] Druilhe A, Letuve S, Pretolani M. Eosinophil apoptosis in asthma [in French]. Pathologie Biologie. 2000;48(6):566-573.

[24] Leung DY, Martin RJ, Szefler SJ, et al. Dysregulation of interleukin 4 , interleukin 5, and interferon gamma gene expression in steroid-resistant asthma. The Journal of Experimental Medicine. 1995;181(1):33-40.

[25] Komai-Koma M, McKay A, Thomson L, et al. Immunoregulatory cytokines in asthma: IL-15 and IL-13 in induced sputum. Clinical \& Experimental Allergy. 2001;31(9):14411448.

[26] Kotsimbos TC, Ernst P, Hamid QA. Interleukin-13 and interleukin-4 are coexpressed in atopic asthma. Proceedings of the Association of American Physicians. 1996;108(5):368-373.

[27] Huang SK, Xiao HQ, Kleine-Tebbe J, et al. IL-13 expression at the sites of allergen challenge in patients with asthma. The Journal of Immunology. 1995;155(5):2688-2694.

[28] Wenzel SE, Schwartz LB, Langmack EL, et al. Evidence that severe asthma can be divided pathologically into two inflammatory subtypes with distinct physiologic and clinical characteristics. American Journal of Respiratory and Critical Care Medicine. 1999;160(3):1001-1008.

[29] Gibson PG, Simpson JL, Saltos N. Heterogeneity of airway inflammation in persistent asthma: evidence of neutrophilic inflammation and increased sputum interleukin-8. Chest. 2001;119(5):1329-1336.

[30] Ohkawa T, Seki S, Dobashi H, et al. Systematic characterization of human $\mathrm{CD}^{+} \mathrm{T}$ cells with natural killer cell markers in comparison with natural killer cells and normal $\mathrm{CD}^{+} \mathrm{T}$ cells. Immunology. 2001;103(3):281-290.

[31] Ferrick DA, Schrenzel MD, Mulvania T, Hsieh B, Ferlin WG, Lepper H. Differential production of interferon- $\gamma$ and interleukin- 4 in response to Th1- and Th2-stimulating pathogens by $\gamma \delta$ T cells in vivo. Nature. 1995;373(6511):255257.

[32] Hayday AC. [gamma][delta] cells: a right time and a right place for a conserved third way of protection. Annual Review of Immunology. 2000;18:975-1026.

[33] Hamzaoui A, Kahan A, Ayed K, Hamzaoui K. T cells expressing the $\gamma \delta$ receptor are essential for Th2-mediated inflammation in patients with acute exacerbation of asthma. Mediators of Inflammation. 2002;11(2):113-119.

[34] Satoh M, Seki S, Hashimoto W, et al. Cytotoxic gammadelta or alphabeta $\mathrm{T}$ cells with a natural killer cell marker, CD56, induced from human peripheral blood lymphocytes by a combination of IL-12 and IL-2. The Journal of Immunology. 1996;157(9):3886-3892.

[35] Loots MA, Lamme EN, Zeegelaar J, Mekkes JR, Bos JD, Middelkoop E. Differences in cellular infiltrate and extracellular matrix of chronic diabetic and venous ulcers versus acute wounds. Journal of Investigative Dermatology. 1998;111(5):850-857.

[36] Pittet MJ, Speiser DE, Valmori D, Cerottini J-C, Romero P. Cutting edge: cytolytic effector function in human circulating $\mathrm{CD}^{+} \mathrm{T}$ cells closely correlates with CD56 surface expression. The Journal of Immunology. 2000;164(3):1148-1152. 


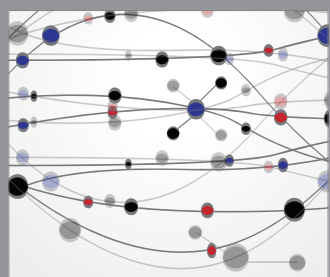

The Scientific World Journal
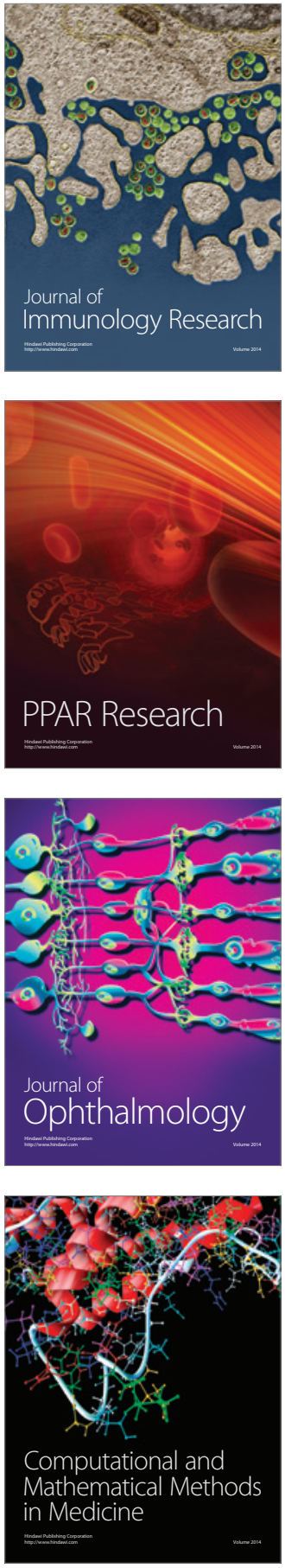

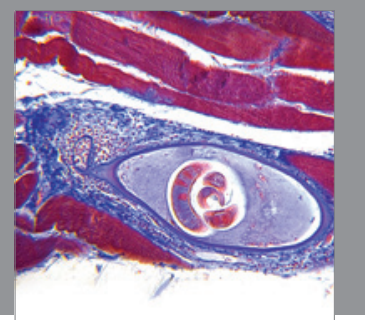

Gastroenterology

Research and Practice
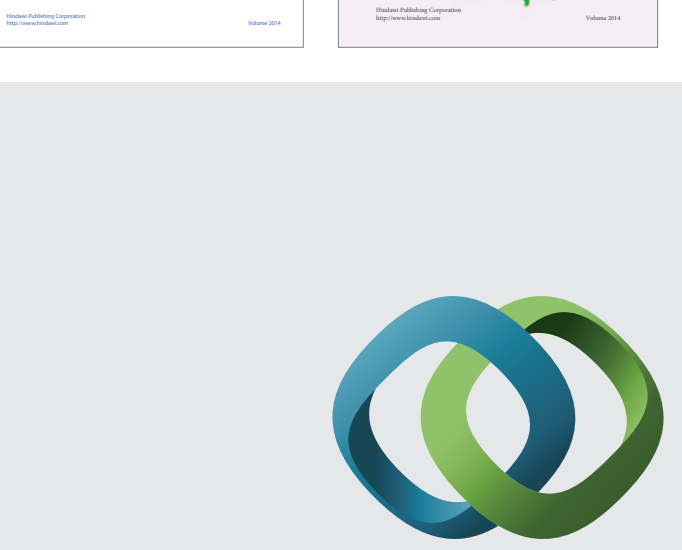

\section{Hindawi}

Submit your manuscripts at

http://www.hindawi.com
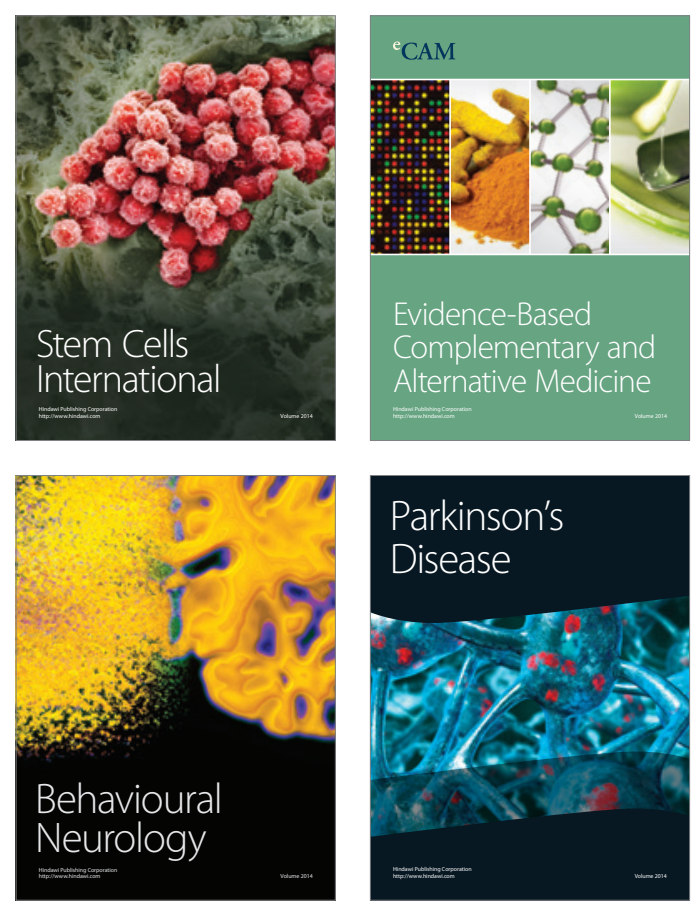

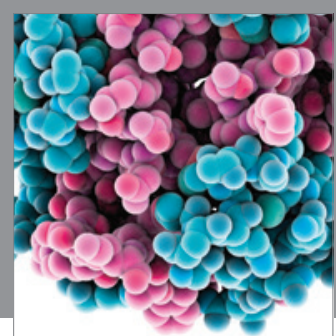

Journal of
Diabetes Research

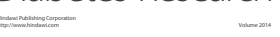

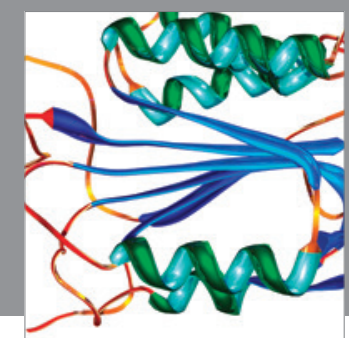

Disease Markers
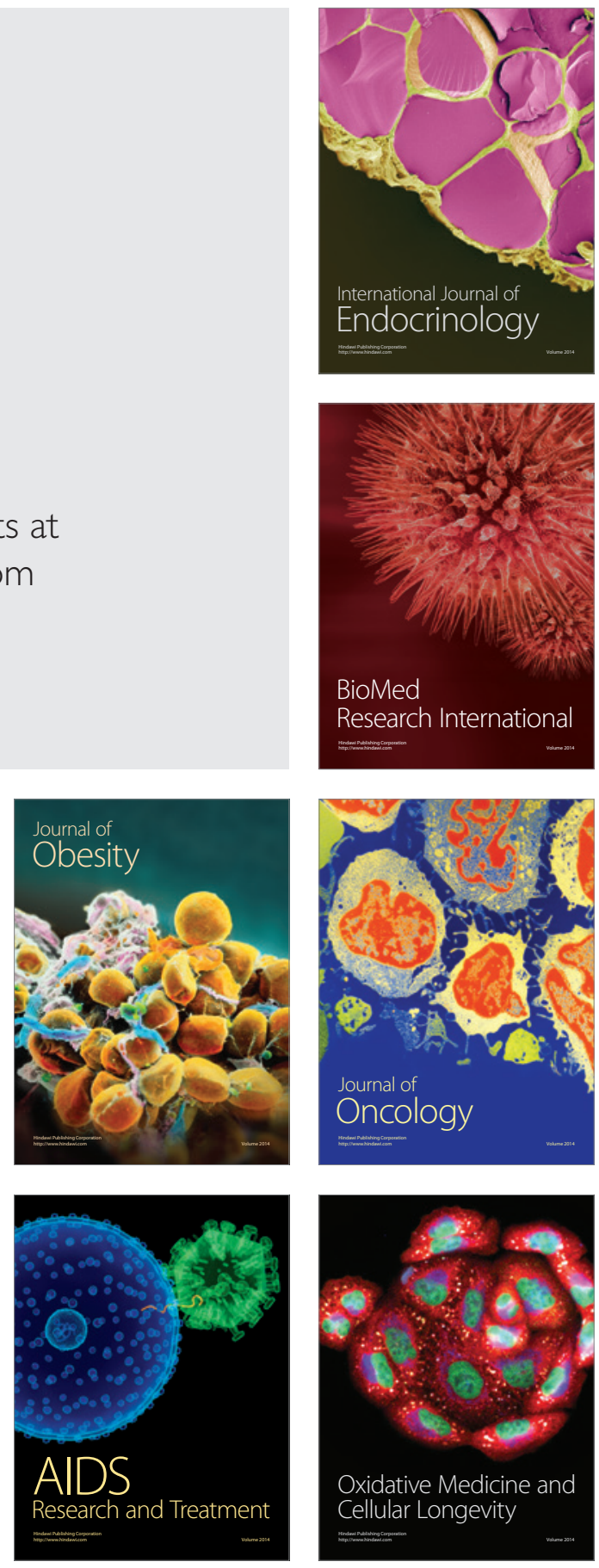